Article

\title{
Banking Development and Economy in Greece: Evidence from Regional Data
}

\section{Christos Floros}

Laboratory of Accounting and Financial Management (LAFIM), Department of Accounting and Finance, Hellenic Mediterranean University, 71004 Heraklion, Crete, Greece; cfloros@hmu.gr

Received: 20 August 2020; Accepted: 12 October 2020; Published: 15 October 2020

\begin{abstract}
This article examines the development of Greek systemic banks for the period 2003-2018, using data such as the ATM network and branches at a regional level. We test the impact of the ATM network and branches on the deposits of Greek commercial banks as well as the impact of local GDP on the regional banking efficiency. The analysis is carried out in two steps, (1) we use the Data Envelopment Analysis (DEA) for efficiency analysis, and (2) we use panel regression models for regression analysis. The results show that branches that operate at small regions are less efficient than those of the larger regions. Furthermore, both the ATMs and the number of branches have a positive relationship with deposits. This means that banks must continue to operate branches and ATMs in Greece. Finally, we show that local GDP helps significantly in increasing regional banking efficiency. The above findings are important given the need to support the local economy with modern banking services in Greece.
\end{abstract}

Keywords: Greek banks; ATM network; branch network; efficiency; deposits; local GDP; panel data; Greek regions

\section{Introduction}

The Greek economy has faced several problems after the 2008 financial crisis. Stournaras (2019) explains that the Greek crisis ${ }^{1}$ has taken a heavy toll on output, incomes and wealth; he reports a high public debt ratio, a high NPL ratio, and high long-term unemployment. According to Meghir et al. (2017, p. vii), "Between 2008 and 2014 [Greeks] income shrank by more than a quarter, their houses lost more than a third of their value, and the unemployment rate more than tripled to reach 27 percent. Even bank deposits ceased being viewed as safe: a bank run took place in the summer of 2015, leading to the imposition of capital controls". Greek banks have been affected by the debt crisis (Avramidis et al. 2020), forcing us to pay special attention to banking efficiency, and further examine if this helps in developing the Greek economy at regional level. The case of Greece is a key issue these days, as it is now going through a period of economic growth ${ }^{2}$, where all sectors of business should contribute at the local level. It is obvious that businesses (such as a bank) play an important role in all economies and are the main creators of jobs and income, innovation, and growth at regional level. Thus, the concept of regional competitiveness is an important issue that helps shape economic policy. The competitiveness depends on many factors - the goal is to have a high and stable level of income so we can talk about regional economic growth. The regions are making competition policies, especially in times of

1 For more information about the Greek crisis, see Galenianos (2015); Christodoulakis (2016); Floros and Chatziantoniou (2017).

2 After several years of financial assistance programs, Greek economy returned to growth. According to the International Monetary Fund, the primary fiscal surplus was 3.8\% in 2018 and the economy grows at $2 \%$ a year. 
recession. The imposition of capital controls ${ }^{3}$ in 2015 due to banking uncertainty led to the digitization of services offered by Greek banks, which face competition by investing more than ever in modern technology. Capital controls impose significance changes in the transactions as follows: transactions with cards increased by 59\% in 2015; POS terminals and POS turnover increased in 2016 by $49 \%$ and $115 \%$, respectively; the number of new debit cards and debit card turnover increased in 2015 by $104 \%$ and $230 \%$, respectively (see Monokroussos et al. 2016). High operating costs and low profitability make it imperative to transform the banking network through the new technological revolution. The development of technology significantly affects the way banks operate as it leads to a shrinking of the banking network and employees, with corresponding economic implications both locally and globally. Theoretically, greater banking development means higher economic growth.

Given the fact that higher regional bank efficiency should promote regional growth (Hasan et al. 2009), this paper makes a contribution to the existing literature examining the banking efficiency level using regional data in Greece. We also examine the effect of number of ATMs and branches on deposits at the regional level, and the impact of regional GDP on banking efficiency. In particular, we investigate the development of the four systemic banks in Greece, using data such as deposits, ATM networks and branches at regional level (Athens, Thessaloniki, other areas-the rest of Greece). Deposits dropped by 45 percent in Greece between January 2009 and July 2015 due to uncertainty about the banks and the Greek economy. Moreover, GDP per capita declined by 26.3 percent between 2007 and 2014 (Meghir et al. 2017); therefore, we also test the link between local economy (in terms of local GDP) with the regional banking efficiency scores. GDP is a key variable which measures economic performance and development at regional level. The research is based on regional bank and economic data for the period 2003-2018. This is an important period for the Greek economy as it includes: (1) the period before and after the 2008 financial crisis, and (2) the imposition of capital controls in Greece in 2015.

The development of any financial system, including banks, shows a positive effect on economic growth, see Williams and Gardener (2003). They argue that European financial deregulation aims to increase $\mathrm{GDP}^{4}$ and raise bank productive efficiency through scale economies resulting from financial sector restructuring (Williams and Gardener 2003, p. 322). They report that, "Regional banking has implications for economic stability since its structure can be considered either a social measure to fund local investment and help regional development, or an economic measure designed to promote the national economic interest".

This paper extends the works of Bernini and Brighi (2018) and Hasan et al. (2009). We consider a number of available variables such as deposits, number of branches, and ATMs as proxies of banking innovation in Greek regional banking (see Bernini and Brighi 2018). Further, we test whether bank efficiency, estimated at regional level, significantly spurs growth using regional GDP (see Hasan et al. 2009). Both papers consider GDP as a key regional economic variable. Spiezia (2003) considers GDP when measuring regional economies and explains that GDP is a key indicator for the design and the assessment of regional policies.

The number of ATMs is important in our analysis as the biggest change in the availability of deposit services in the last three decades has been the introduction of ATMs to increase and replace the traditional bank branch. The increased availability of ATMs has benefited the bank's customers as extending ATMs to new areas means that services are usually available $24 \mathrm{~h}$ a day (24/7). Humphrey (1994) reports that while ATMs were able to reduce transaction costs, depositors increased the number of transactions. According to Zilberfarb (1989), ATMs reduce the cost-time element, i.e., they reduce the time customers have to spend in the bank. Thus, in theory, the use of ATMs increases deposits.

3 Greek banking uncertainty was related to the capital controls imposed in Greece in June 2015 in an attempt to avoid an uncontrolled bank run; see Antonakakis et al. (2019); Samitas and Polyzos (2016).

4 Williams and Gardener (2003) suggest that segmentation of the European banking system could realize higher growth rates in European regions through information asymmetries. For more information about European regional banking, see Williams and Gardener (2003). 
As ATM use increases, more withdrawals will be made. Furthermore, increasing ATMs leads to better availability, and theoretically more use. In general, the use of ATMs reduces the cost of transactions through demand deposit accounts. So, the introduction of ATMs is expected to increase demand. Zilberfarb (1989) examines this case and proves that a 1\% increase in the number of ATMs increases real demand deposits by $1 \%$. Moreover, Floros and Giordani (2008) report that banks earn more revenue (and increase their efficiency) by offering services such as ATMs. They examine how useful the number of ATMs is for modeling and assessing the efficiency of Greek banks. They find that big banks are more efficient than medium and small banks. In addition, Greek banks with a large number of ATMs are more efficient than banks with a smaller number of ATMs. Recently, Shamim et al. (2017) empirically examined the direct and indirect effects of ATMs on the performance of the Japanese banks and report that banks minimize costs and save money by using ATMs; they argue that low-cost electronic channels can significantly reduce costs and enhance efficiency.

To the best of our knowledge, this is the first empirical study about regional banking development and economy in Greece. Policy makers are interested in assessing economic performances between regions (Spiezia 2003); hence, this study contributes to the existing banking and regional economics literature in several ways as given above and recommends important results. We find that branches that operate at small regions are less efficient than those of the larger regions. Furthermore, both the ATMs and the number of branches have a positive relationship with deposits. Finally, we show that local GDP helps significantl y in increasing regional banking efficiency. The results of this research can lead us to useful regional policy conclusions for the banking sector. The structure of the work is as follows: the next section presents the literature on the subject of the research. The following (Section 3) is a description of the research methodology. Finally, the study summarizes and concludes the results of the research and suggests further research in Section 4.

\section{Literature Review}

Regional competitiveness can be defined as the ability of regions to achieve economic growth relative to other regions of a similar growth stage located in the same state. Floros et al. (2014) analyzed the performance of Greek manufacturing companies by sector and region and reported that the competitiveness of a region is related to the competitiveness of its companies, which depends on their financial performance but also on the degree of efficiency of their operation. It is accepted that banks are important companies for the regional economic development of a region because they provide financing, create employment, and thus play an important role in all local economies. According to theory and international literature, banks' efficiency is a way to investigate their competitiveness and productivity. Improving the efficiency of banks is an important goal nowadays, especially after the global economic crisis of 2008, where banks collapsed (e.g., Lehman Brothers) and their efficiency levels decreased ${ }^{5}$. To compute efficiency, most banking studies employ the Data Envelopment Analysis (DEA), which is flexible in the way that it does not require the specification of a production function (see Tziogkidis et al. 2018). Key variables in estimating efficiency are financial ratios as well as number of branches, ATMs, employers, etc. Understanding the relationship between inputs used in banks and their return is a key condition for efficiency. Some of the first works on the efficiency of bank branches are Sherman and Gold (1985) for the USA, Parkan (1987) for Canada, Oral and Yolalan (1990) for Turkey, Soteriou and Zenios (1999) for Cyprus, Schaffnit et al. (1997) for Canada, Hartman et al. (2001) for Sweden, Wu et al. (2006a, 2006b) for Canada, Pastor et al. (2006) for Europe, Sherman and Ladino (1995) and Berger et al. (1997) for the USA, and Portela and Thanassoulis (2007) for Portugal.

5 Asmild and Zhu (2016) find that the 2008 financial crisis has affected negatively European banks efficiency levels over the period 2006-2009. Degl'Innocenti et al. (2017a) find that, after 2010, European banks' efficiency levels have decreased, suggesting a negative effect when the sovereign debt crisis appeared. Spokeviciute et al. (2019) report that crises periods have a disproportionate effect on young banks regardless of their efficiency levels. For a brief review of the relative literature, see Kevork et al. (2017), Degl'Innocenti et al. (2017b). 
For Greece, the first works were by Vassiloglou and Giokas (1990), Giokas (1991), Athanassopoulos (1997), and Pavlopoulos and Kouzelis (1989). In general, they show that bank branches are not affected by competition, technology, or location. However, Walter (1999) states that local and regional retail banking markets in the United States have become more competitive. For Europe, Walter (1999) argues that local customer preferences are strong. Williams and Gardener (2003) also examine the importance of banks' productive efficiency. The results from the empirical investigation show that locally operating banks are more efficient, while regional banks are more economically efficient than other banks. They note that local savings banks are improving their efficiency over time. Donatos and Gikas (2008) examine the efficiency of Greek banks for 2002. Efficiency is examined on the branch's ability to provide a maximum number of transaction services at the lowest possible operating costs. Branches that provide products to businesses and individuals (large stores) are more functional compared to branches that provide products only to individuals. They also report that there is no close link between the efficiency and profitability of a bank branch in Greece. In general, a low-profit bank branch may not necessarily perform less efficiently than a high-profit one. More specifically, a bank branch may not be very efficient in terms of the number of transactions, but it may be quite profitable, or vice versa. Further, Gaganis et al. (2009) examine the efficiency and productivity of Greek bank branches for the period 2002-2005. Among other things, they identify the impact of internal and external factors on efficiency and productivity. The results show that both the staff account and the per capita income account in the local market have a significant impact on bank efficiency, while the ratio of loans to total assets has a significant impact only on pure technical efficiency. Hasan et al. (2009) provide evidence of a positive relation between banking quality and economic growth in several regions within 11 countries of European Union. Recently, Bernini and Brighi (2018) examine the effects of branch network expansion on the cost efficiency of Italian cooperative banks over the period 2006-2013. They report a negative impact on efficiency; also, efficient local banks boost the local economy. Finally, Coccorese and Shaffer (2020) report that banks contribute to the real economy by directing savings to investment opportunities. They examine the impact of Italian cooperative banks on local economic development and find that banks are associated with enhanced income, employment and firm's growth rates.

In the present study, we examine the efficiency of Greek systemic banks ${ }^{6}$ (National Bank of Greece, Alpha Bank, Piraeus Bank, Eurobank) at the regional level, as a way to measure their performance, using the well-known Data Envelopment Analysis methodology. For this, we focus on the most competitive regions of the country (Athens, Thessaloniki, Other areas-the rest of Greece ${ }^{7}$ ). Since one of the main goals of the banks is to increase their efficiency, understanding it (through key factors such as ATMs, Branches, and Deposits) can result in the improvement of the performance of Greek banks at the regional level. Finally, we examine the effect of regional GDP (as a measure of economic development and growth) on the banking efficiency; in other words, we test the hypothesis if a GDP increase leads to an increase on the banking efficiency scores at regional level. Based on the existing papers on banking performance, there are many factors that explain banking efficiency (see Altunbas and Molyneux 1996; Dietsch and Lozano-Vivas 2000; Maudos et al. 2002; Berger and Mester 2003; Valverde et al. 2007, among others). However, we only consider the number of ATMs, Branches, Deposits, and GDP for our analysis, as these are key variables for our hypotheses and are available at regional level for most countries such as Greece. Furthermore, these are factors which are considered from similar studies on regional banking, such as Bernini and Brighi (2018) and Hasan et al. (2009).

6 The Greek banking system includes four systemic banks that operate branches in the whole country. These are: Piraeus Bank (founded in 1916, it is the largest bank in terms of assets), National Bank of Greece (founded in 1841, it is the largest bank in terms of deposits), Eurobank (founded in 1990, it is the second largest bank in Greece), and Alpha Bank (founded in 1879 , it is the largest bank in terms of market capitalization).

7 Following the official demographics of Greece as of 2011 (with total population of c. $10.8 \mathrm{~m}$ ), the largest Metropolitan city is Athens which is the capital of Greece, with population of c. $4 \mathrm{~m}$. The second-largest Metropolitan city is Thessaloniki with population of c. $1.3 \mathrm{~m}$. Based on the above official statistics of population reported from the Hellenic Statistical Authority and the available data, we consider three large regions for our analysis: Athens, Thessaloniki, Other areas-the rest of Greece. 


\section{Methodology}

\subsection{Banking Efficiency}

Banks operate as businesses and therefore aim to maximize their profits and share price. High-street banks are not that different from any other business; they provide services to people, SMEs, as well as larger firms. The literature has focused on the measuring efficiency and competitiveness of banks (Tan and Floros 2020, 2018, 2014, 2013, 2012). The efficiency is measured through the inputs (production rates) and the outputs of the banks. Banks use funds derived from deposits, but also labor, technological, building equipment, etc. According to the existing literature, we can measure the product produced by a bank following (1) the production approach or (2) the intermediation approach. In the first approach, banks are perceived as service providers for those who maintain accounts. The product is therefore measured by the number of transactions carried out over a given period of time (Delis 2009). The second approach (intermediation), means that banks appear as capital intermediaries between positive and negative savers. Thus, balance sheet data are used for loans, deposits, etc. Here, the question arises as to whether deposits are inputs or outputs. Deposits have the characteristics of productive factors (as a source for financing loans), but also of a product since they constitute a service of the bank as a measure of liquidity (see Delis 2009). Therefore, there are studies that use deposits as input and others as output. According to a recent study, Floros et al. (2020) examine the efficiency of banks using recent data from PIGS countries (i.e., Portugal, Italy, Greece, and Spain), which have faced debt problems during and after the 2008 financial crisis period. Using a two-step approach based on the impact of many balance sheet elements on cash flows and DEA analysis, they extended previous studies by paying attention to the dilemma of deposits, and found that deposits may be an output variable, owing to liquidity issues that play a major role in the efficiency of PIGS' banking sector.

According to the literature, there are two main methods for measuring efficiency (1) the parametric method and (2) the non-parametric or linear programming method. With these methods, we construct an efficient production limit and find the level of efficiency. The most well-known (and acceptable due to advantages) linear programming method is the Data Envelopment Analysis or DEA, which we briefly present below. The DEA method does not take into account the existence of a random error; for more details, see Spokeviciute et al. (2019).

\subsection{Measuring Efficiency with DEA}

The method we use to evaluate efficiency of Greek banks at regional level is DEA, which was developed by (Charnes et al. 1978). DEA is widely used to evaluate the efficiency of any organization or business such as a bank. The main purpose of DEA is to construct a non-parametric envelopment over the data points, so that all observations are above or below the production frontier. DEA measures the efficiency of each bank that is obtained as a maximum of a ratio of weighted outputs to weighted inputs; it minimizes specific inputs and maximizes outputs. The efficiency of each economic unit is calculated by comparing the use of inputs and outputs at points above the output limit. DEA considers the economic unit as a production unit that consumes inputs (financial resources), in order to produce a total of outputs. If it is above the output limit, the efficiency is equal to $1 \%$ or $100 \%$. In other words, a decision-making unit (DMU) with a score less than one is considered to be an inefficient unit relatively with other DMUs with scores equal to one which are considered to be efficient (Floros and Giordani 2008). Charnes et al. (1978) propose a DEA model with constant returns (CRS). The following equations show the linear programming methods, according to the DEA-CRS model given by:

$$
\begin{aligned}
& \min _{\theta, \lambda} \theta, \\
& \text { subject to } \\
& -y_{i}+Y \lambda \geq 0, \\
& \theta x_{i}-X \lambda \geq 0, \\
& \lambda \geq 0
\end{aligned}
$$


where $\theta$ is a scalar and $\lambda$ is a $\mathrm{N} \times 1$ vector of constants, $Y$ represents all input and output data for $\mathrm{N}$ firms (banks), $x_{i}$ are individual inputs, and $y_{i}$ are outputs for the $i$ th firms. The efficiency score for each DMU is given by $\theta$ and takes values between 0 and 1 , which indicates the level of efficiency (Floros et al. 2020). Benefits of choosing DEA-CRS include that it has a faster statistical convergence rate as well as a greater discriminatory power, relative to the VRS approach (Du et al. 2018). For more details about the DEA-CRS method, see Tziogkidis et al. (2018) and Du et al. (2018).

We note that, various factors have been proposed from previous studies that are related to the level of efficiency of banks and relate to market structure, regulation, level of bank risk, mergers and acquisitions, organizational structure of banks, etc. In the present work we follow similar works to measure the efficiency of banks by considering key factors such as deposits, the number of ATMs and Branches, for each systemic Greek bank (National Bank, Alpha Bank, Piraeus Bank, Eurobank) and region (Athens, Thessaloniki, Other areas-the rest of Greece) over the period 2003-2018. For the empirical analysis on the efficiency of Greek banks we employ the DEA-CRS (input oriented $^{8}$ ) methodology with the following data: Inputs (Branch Number, ATM Number), and Outputs (Total Deposits).

\subsection{Panel Regressions}

We estimate the relationship between deposits with the number of ATMs and branches using panel data. Specifically, we extend previous studies (e.g., Zilberfarb 1989; Humphrey 1994) on the performance of banks at the regional level by examining the following three hypotheses for Greece.

Hypothesis 1 (H1). There is a positive relationship between the number of ATMs and regional deposits.

Hypothesis 2 (H2). There is a positive relationship between the number of branches and regional-level deposits.

Hypothesis 3 (H3). There is a positive relationship between the local economy (GDP) and regional banking efficiency scores.

By estimating panel data, we can include data for $\mathrm{N}$ layered units (e.g., banks at the regional level) observed at different time periods. Thus, to test Hypotheses 1 and 2, we estimate a simple linear model, of the form:

$$
\text { Deposits }_{i t}=\alpha+\beta \text { ATM }_{i t}+\gamma \text { Branches }_{i t}+u_{t}
$$

where the independent logarithmic variables ATM and Branches have $i$ and $t$ indices for $i=1,2,3$ layered units (Athens, Thessaloniki, Other areas-the rest of Greece) and T time periods (2003-2018). The dependent variable Deposits is also in logarithms.

Similarly, to test Hypothesis 3, we estimate model of the form:

$$
\text { Efficiency }_{i t}=\alpha+\beta G_{\text {DDP }}+u_{t}
$$

Both variables Efficiency and GDP are in logarithms.

For our empirical analysis, we use a balanced panel with a sample size of 48 observations; in our case, time periods $(\mathrm{T}=16)$ are greater than the units $(\mathrm{N}=3)$. So, our dataset can be characterized as a long panel $(\mathrm{T}>\mathrm{N})$. Panel data analysis is popular because it allows the inclusion of data and chronological periods and is considered an efficient method of assessment, whether we have balance or not. In estimating the above model, we can follow the method of fixed effects or random effects. The difference between these methods is that the method of random effects handles the constants for

8 In the context of CRS formulation, the efficiency score with output orientation is equivalent (and reciprocal) to that in the input orientation, which is an advantage of using CRS formulation (Du et al. 2018, p. 752). 
each unit not as fixed but as random parameters. Here we must emphasize that the Hausman test helps to choose between the model of fixed and random effects; it compares their estimates of coefficients. For panel data, the appropriate choice between fixed and random effect methods involves examining whether the independent variables are correlated with unit effects (Asteriou and Hall 2015). In other words, we test the hypothesis that the preferred model is random effects against the alternative fixed effects (i.e., Hausman tests whether the error term is correlated with the regressors or not). In our case, the Hausman test shows that the OLS model with random effects is superior for our analysis (these results are available upon request).

\section{Results and Conclusions}

\subsection{DEA Results}

Figure 1 shows the number of ATMs and Branches at regional level for the years 2003-2018, while Figures 2 and 3 show the Deposits of the branches per region and local GDP for the same period, respectively. The main sources for banking data are the Hellenic Bank Association and the Bank of Greece; the source for the GDP data is the Hellenic Statistical Authority. Summary statistics for all variables included in the empirical analysis (not provided here) show that they are not normally distributed, since the values of skewness and kurtosis are not equal to zero ad three, respectively. Further, there is evidence of no correlation among all the examined variables with the efficiency variable.

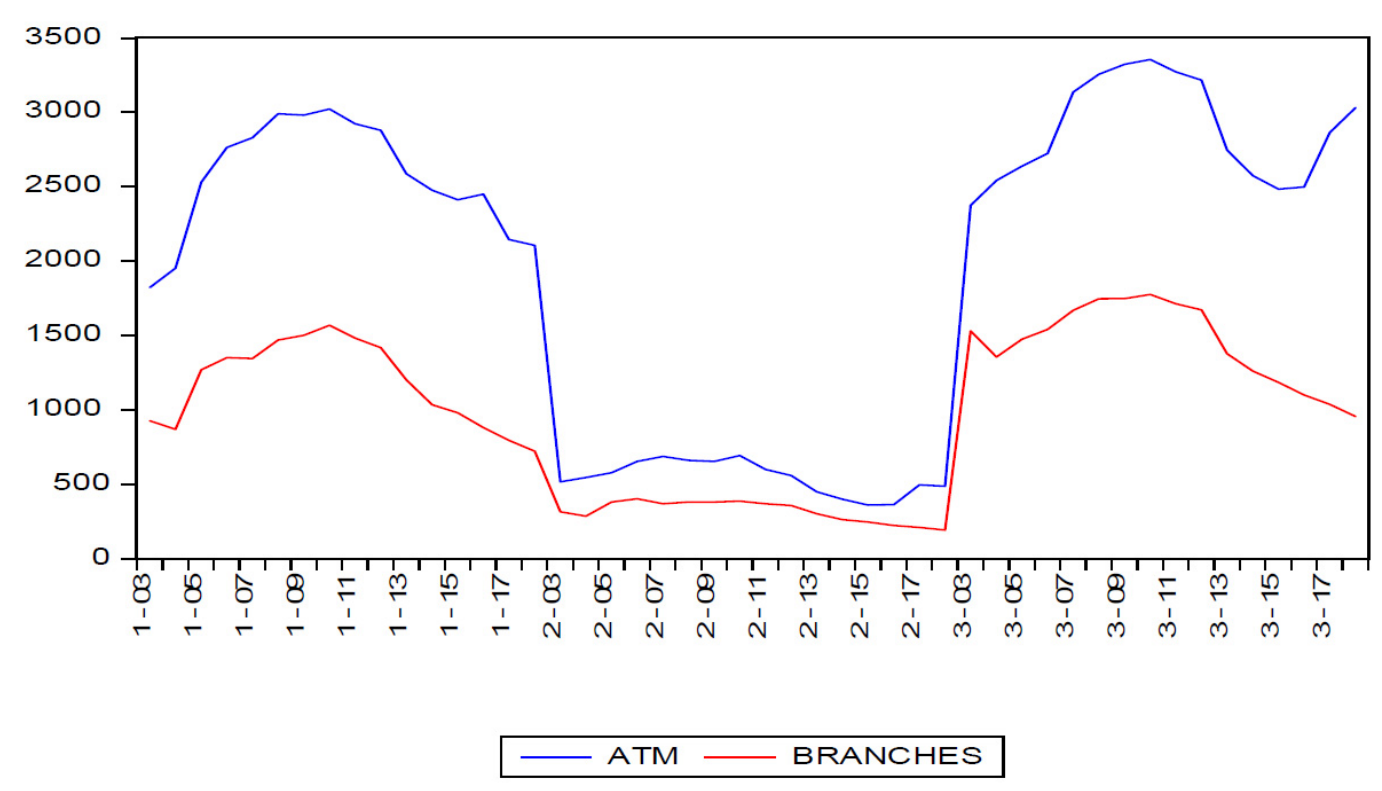

Figure 1. ATM and Branches per region/year (2003-2018). Notes: Region 1 (Athens), Region 2 (Thessaloniki), Region 3 (Other Areas—the rest of Greece). Source of data: Hellenic Bank Association. 


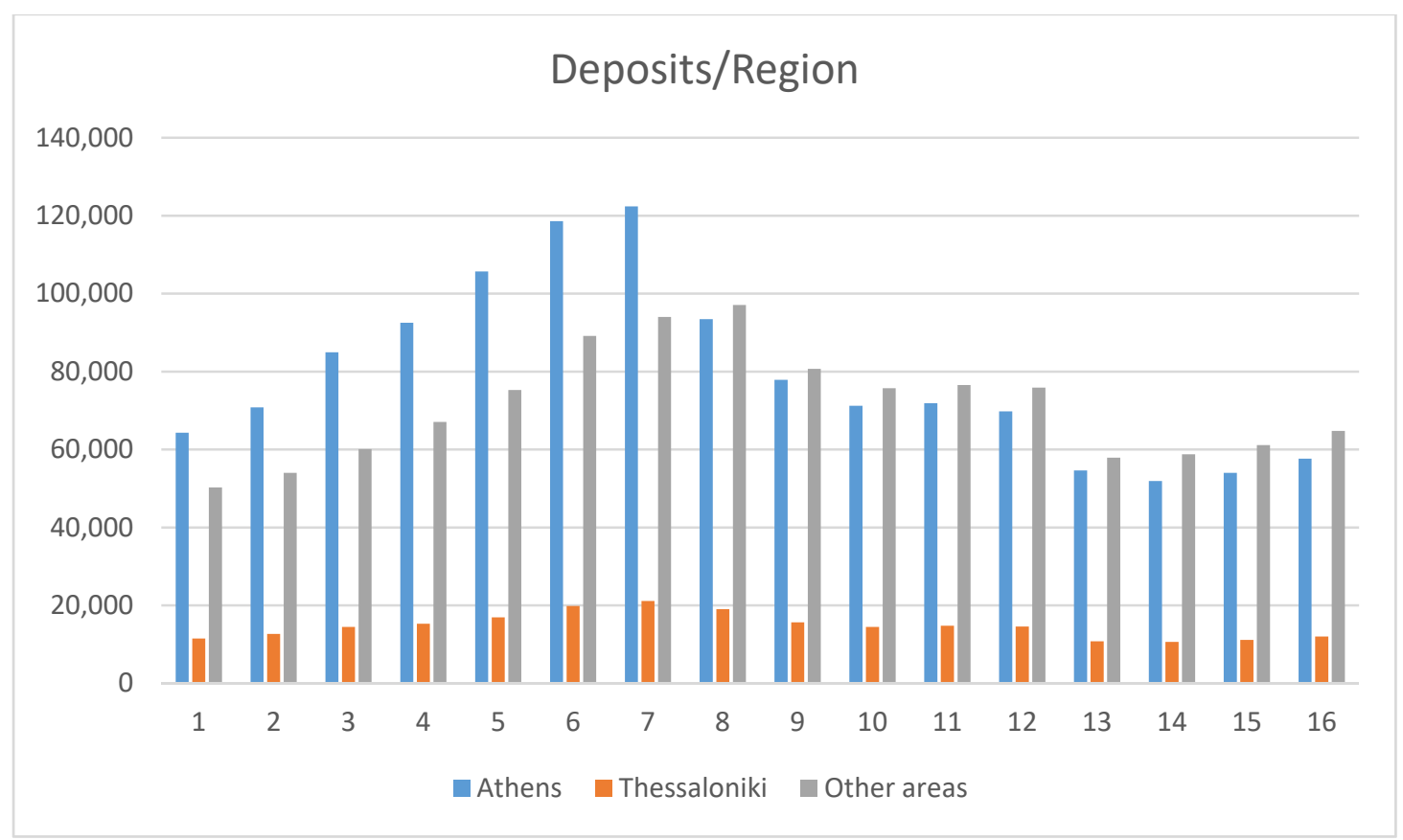

Figure 2. Deposits in mil. euros per region/year (2003-2018). Source of data: Bank of Greece.

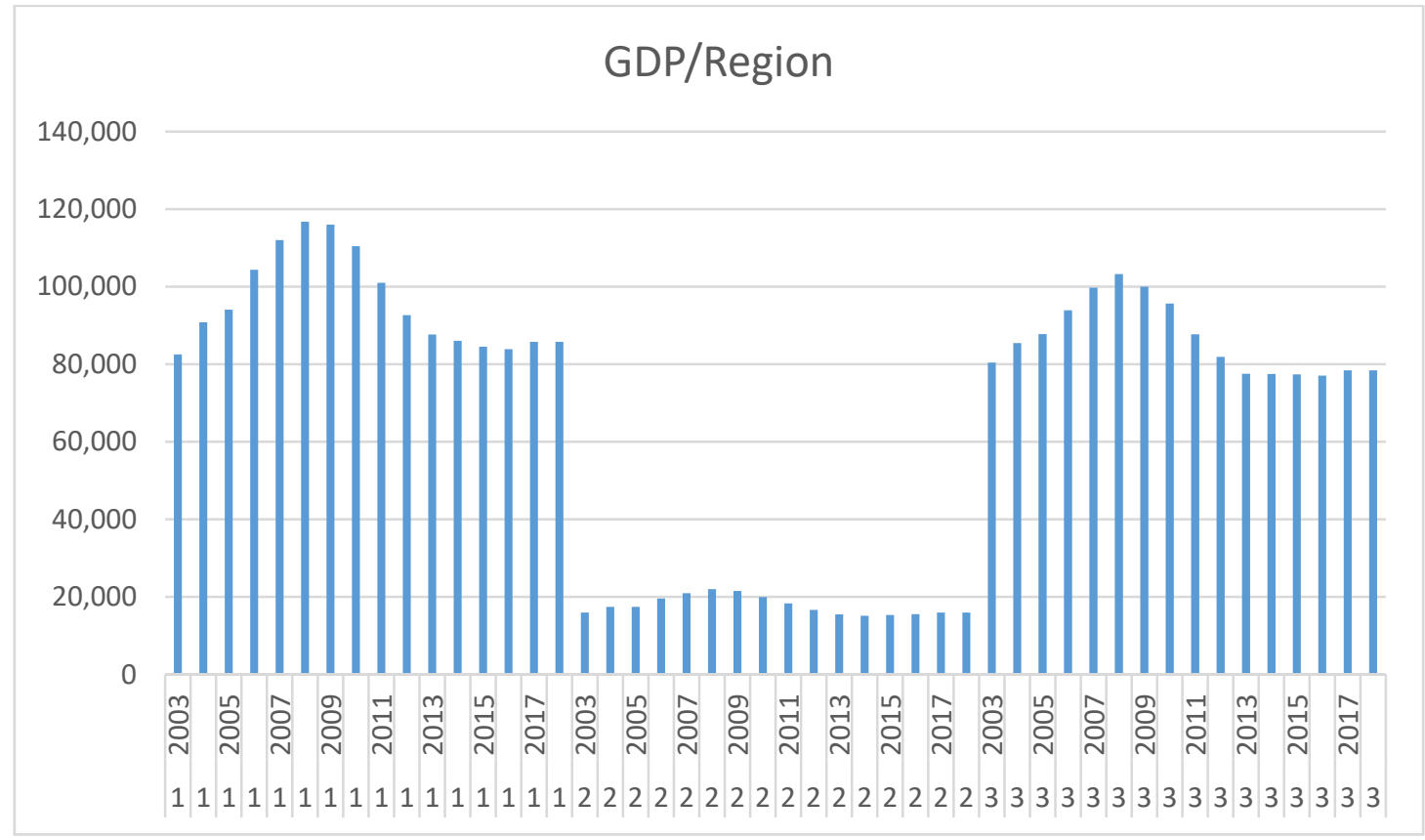

Figure 3. GDP in mil. euros per region/year (2003-2018). Notes: Region 1 (Athens), Region 2 (Thessaloniki), Region 3 (Other Areas—the rest of Greece). Source of data: Hellenic Statistical Authority.

The results from DEA, obtained using PIM-DEA software, show that the average efficiency scores of Athens, Thessaloniki, and Other areas-the rest of Greece for the examined period were estimated at $100 \%, 85 \%$, and $81 \%$, respectively. Furthermore, the efficiency of banks in two Regions (Athens, Other areas-the rest of Greece) was assessed, where Thessaloniki was included in the Other areas-the rest of Greece. The results from DEA in this case, were 100\% for Athens and $83 \%$ for the rest of the regions. In conclusion, the empirical analysis from DEA method gives the following results: over the period 2003-2018, the banks of the Athens region are the most efficient over time (DEA results are available upon request). 


\subsection{Panel Data Results}

The results from panel data analysis using EViews software are presented in Tables 1 and 2. Table 1 presents the results for Hypotheses 1 and 2 (Equation (1)), where both the number of ATMs and the branches of the regions for the years 2003-2018 have a positive and significant effect on deposits. The results show that the number of branches helps significantly in increasing regional deposits. Further, Table 2 presents the results for Hypothesis 3 (Equation (2)), where the local GDP of the examined regions for the years 2003-2018 has a positive and significant effect on the efficiency scores. The results show that local GDP helps significantly in increasing regional banking efficiency in Greece.

Table 1. Panel data results (Equation (1)).

\begin{tabular}{ccccc}
\hline \multicolumn{5}{c}{ Dependent Variable: DEPOSITS } \\
\hline \multicolumn{5}{c}{ Method: Panel Least Squares } \\
\hline Variable & Coeff. & Std. Error & t-Statistic & Prob. \\
\hline$\alpha$ & 5.332780 & 0.859322 & 6.205798 & $0.0000 *$ \\
ATM & 0.279117 & 0.161614 & 1.727057 & $0.0913^{*}$ \\
BRANCHES & 0.489688 & 0.137343 & 3.565444 & $0.0009 *$ \\
\hline \multicolumn{5}{c}{}
\end{tabular}

Table 2. Panel data results (Equation (2)).

\begin{tabular}{ccccc}
\hline \multicolumn{5}{c}{ Dependent Variable: Efficiency } \\
\hline \multicolumn{5}{c}{ Method: Panel Least Squares } \\
\hline Variable & Coeff. & Std. Error & t-Statistic & Prob. \\
\hline$\alpha$ & -280.3578 & 115.5239 & -2.426839 & $0.0225^{*}$ \\
GDP & 26.44015 & 10.63201 & 2.486844 & 0.0196 \\
\hline \multicolumn{6}{c}{}
\end{tabular}

For robustness checks ${ }^{9}$, we test all three hypotheses using data for two large regions (Athens, Other areas-the rest of Greece); i.e., Thessaloniki was included in the Other areas-the rest of Greece. The results are qualitative similar to the reported results as given in Tables 1 and 2 above.

\subsection{Summary and Conclusion}

The Greek economy as well as the Greek banks have been operating in recent years in a highly competitive environment despite the financial problems caused by the 2008 financial crisis. Galenianos (2015) reports that Greek banks have been hit by recession, the haircut on public debt and a huge drop in deposits. Avramidis et al. (2020) argue that "Greek banks suffered large losses from the sovereign debt restructuring. Banks faced severe liquidity constraints because they were gradually excluded from the interbank market following the downgrading of the Greek sovereign debt by rating agencies. The recession affected negatively the income of businesses and their ability to service their debt, thus corporate non-performing loans (NPLs) increased to 34.3\% in 2015, depleting further the banks' capital ratios".

According to Stournaras (2019, p. 127), "the Greek crisis has taken a heavy toll of incomes, employment and wealth". The imposition of capital controls in 2015 led to the digitization of services offered by Greek banks. Banks face competition by investing more than ever in modern technology. High operating costs and low profitability make it imperative to transform the banking network through the new technological revolution. Development of technology significantly affects the way banks operate as it

9 These results are not reported, but available from the author upon request. 
leads to a shrinking of the banking network and employees, with corresponding economic implications both locally and in general. This article examines the development and performance of banks in Greece in the period 2003-2018, using data such as the ATM network and branches at regional level (Athens, Thessaloniki, Other areas-the rest of Greece). Specifically, our work examines the effect of ATM and branch numbers on Greek bank deposits as well as the effect of local GDP on banking efficiency. GDP is a key variable which measures economic performance at regional level; it monitors the economic development of any region. The analysis is done in two stages, (1) the efficiency is examined with the Data Envelopment Analysis (DEA) and (2) the effect of the above factors on the deposits and local GDP is further investigated with a panel model. The results show that the branches of Greek banks operating at the regional level (small areas) are less efficient than those of the larger areas (Athens, Thessaloniki). Furthermore, both the ATMs and the number of branches have a positive relationship with deposits. This means that banks must continue to operate branches and ATMs regionally, as they help increase deposits. We also show that local GDP helps significantly in increasing regional banking efficiency; this is in line with previous studies. Therefore, policy makers should find ways to increase local GDP in order to make Greek banks healthier; we also conclude that Greek banks play a major role in the regional economic policy as they improve economic performance.

The above findings are important given the need to support the local economy with modern banking services. A limitation of the current study is that not all banking and economic data are available at regional level. Further empirical investigation of the efficiency of Greek bank branches should be analyzed with more data using a dynamic panel model, which can examine how different factors such as the size of branches, the number of employees, and regional unemployment can affect both their efficiency and profitability in combination with other regional economic indicators.

Funding: This research received no external funding.

Conflicts of Interest: The author declares no conflict of interest.

\section{References}

Altunbas, Yener, and Phil Molyneux. 1996. Economies of scale and scope in European banking. Applied Financial Economics 6: 367-75. [CrossRef]

Antonakakis, Nikolaos, Davis Gabauer, and Rangan Gupta. 2019. Greek Economic Policy Uncertainty: Does it Matter for Europe? Evidence from a Dynamic Connectedness Decomposition Approach. Physica A: Statistical Mechanics and Its Applications 535: 122280. [CrossRef]

Asmild, Mette, and Minyan Zhu. 2016. Controlling for the use of extreme weights in bank efficiency assessments during the financial crisis. European Journal of Operational Research 251: 999-1015. [CrossRef]

Asteriou, Dimitrios, and Stephen G. Hall. 2015. Applied Econometrics, 3rd ed. London: Macmillan International Higher Education.

Athanassopoulos, Andreas D. 1997. Service quality and operating efficiency synergies for management control in the provision of financial services: Evidence from Greek bank branches. European Journal of Operational Research 98: 300-13. [CrossRef]

Avramidis, Panagiotis, Ioannis Asimakopoulos, Dimitris Malliaropoulos, and Nickolaos G. Travlos. 2020. Do banks appraise internal capital markets during credit shocks? Evidence from the Greek Crisis. Journal of Financial Intermediation. [CrossRef]

Berger, Allen N., and Loretta J. Mester. 2003. Explaining the dramatic changes in performance of US banks: Technological change, deregulation, and dynamic changes in competition. Journal of Financial Intermediation 12: 57-95. [CrossRef]

Berger, Allen N., John H. Leusner, and John J. Mingo. 1997. The efficiency of bank branches. Journal of Monetary Economics 40: 141-62. [CrossRef]

Bernini, Cristina, and Paola Brighi. 2018. Bank branches expansion, efficiency and local economic growth. Regional Studies 52: 1332-45. [CrossRef]

Charnes, Abraham, William W. Cooper, and Edwardo Rhodes. 1978. Measuring the efficiency of decision making units. European Journal of Operational Research 2: 429-44. [CrossRef] 
Christodoulakis, Nicos. 2016. Greek crisis in perspective: Origins, effects and ways-out. In Banking Crises: Perspectives from the New Palgrave Dictionary of Economics. Edited by Garret Jones. Hampshire: Palgrave MacMillan, pp. 119-43.

Coccorese, Paolo, and Sherrill Shaffer. 2020. Cooperative banks and local economic growth. Regional Studies. [CrossRef]

Degl'Innocenti, Marta, Stavros A. Kourtzidis, Zeljko Sevic, and Nickolaos G. Tzeremes. 2017a. Investigating bank efficiency in transition economies: A window-based weight assurance region approach. Economic Modelling 67: 23-33. [CrossRef]

Degl'Innocenti, Marta, Stavros A. Kourtzidis, Zeljko Sevic, and Nickolaos G. Tzeremes. 2017b. Bank productivity growth and convergence in the European Union during the financial crisis. Journal of Banking E Finance 75 : 184-99.

Delis, Manthos. 2009. Banking Lecture Notes. Ioannina: University of Ioannina.

Dietsch, Michel, and Ana Lozano-Vivas. 2000. How the environment determines banking efficiency: A comparison between French and Spanish industries. Journal of Banking \& Finance 24: 985-1004.

Donatos, Gekrge S., and Dimitris I. Gikas. 2008. Relative Efficiency in the branch network of a Greek bank: A quantitative analysis. European Research Studies 3: 53-72.

Du, Kai, Andrew C. Worthington, and Valentin Zelenyuk. 2018. Data envelopment analysis, truncated regression and double-bootstrap for panel data with application to Chinese banking. European Journal of Operational Research 265: 748-764. [CrossRef]

Floros, Christos, and Ioannis Chatziantoniou. 2017. The Greek Debt Crisis: In Quest of Growth in Times of Austerity. London: Palgrave MacMillan.

Floros, Christos, and Georgia Giordani. 2008. ATM and Banking efficiency: The case of Greece. Banks and Bank Systems 3: 55-64.

Floros, Christos, Zacharias Voulgaris, and Christos Lemonakis. 2014. Regional firm performance: The case of Greece. Procedia Economics and Finance 14: 210-19. [CrossRef]

Floros, Christos, Constantin Zopounidis, Yong Tan, Christos Lemonakis, Alexandros Garefalakis, and Efthalia Tabouratzi. 2020. Efficiency in Banking: Does the Choice of inputs and outputs matter? International Journal of Computational Economics and Econometrics 10: 129-48. [CrossRef]

Gaganis, Chrysovalantis, Aggeliki Liadaki, Michael Doumpos, and Constantin Zopounidis. 2009. Estimating and analyzing the efficiency and productivity of bank branches. Managerial Finance 35: 202-18. [CrossRef]

Galenianos, Manolis. 2015. The Greek Crisis: Origins and Implications. Research Paper No 16. Athens: Hellenic Foundation for European and Foreign Policy (ELIAMEP).

Giokas, Dimitris I. 1991. Bank branch operating efficiency: A comparative application of DEA and the loglinear model. Omega 19: 549-57. [CrossRef]

Hartman, Thomas E., James E. Storbeck, and Patricia Byrnes. 2001. Allocative efficiency in branch banking. European Journal of Operational Research 134: 232-42. [CrossRef]

Hasan, Iftekhar, Michael Koetter, and Michael Wedow. 2009. Regional growth and finance in Europe: Is there a quality effect of bank efficiency? Journal of Banking and Finance 33: 1446-53. [CrossRef]

Humphrey, David B. 1994. Delivering deposit services: ATMs versus Branches. Federal Reserve Bank of Richmond Economic Quarterly 80: 59-81.

Kevork, Ilias S., Jenny Pange, Panayiotis Tzeremes, and Nickoloas G. Tzeremes. 2017. Estimating Malmquist productivity indexes using probabilistic directional distances: An application to the European banking sector. European Journal of Operational Research 261: 1125-40. [CrossRef]

Maudos, Joaquin, Jose M. Pastor, Francisco Pérez, and Javier Quesada. 2002. Cost and profit efficiency in European banks. Journal of International Financial Markets, Institutions and Money 12: 33-58. [CrossRef]

Meghir, Costas, Christopher A. Pissarides, Dimitri Vayanos, and Nikolaos Vettas. 2017. Beyond Austerity: Reforming the Greek Economy. Cambridge: The MIT Press.

Monokroussos, Platon, Anna Dimitriadou, Ioannis Gkionis, Stylianos G. Gogos, Paraskevi Petropoulou, and Theodoros Stamatiou. 2016. One Year Capital Controls in Greece. Eurobank Economic Research. Available online: https://www.eurobank.gr/Uploads/Reports/GLOBAL_FOCUS_NOTE_20160805. pdf (accessed on 12 October 2020).

Oral, Muhittin, and Reha Yolalan. 1990. An empirical study on measuring operating efficiency and profitability of bank branches. European Journal of Operational Research 46: 282-94. [CrossRef] 
Parkan, Celik. 1987. Measuring the efficiency of service operations: An application to bank branches. Engineering Costs and Production Economics 12: 237-42. [CrossRef]

Pastor, Jesus T., C. A. Knox Lovell, and Henry Tulkens. 2006. Evaluating the financial performance of bank branches. Annals of Operations Research 145: 321-37. [CrossRef]

Pavlopoulos, Panayiotos G., and A. K. Kouzelis. 1989. Cost behaviour in the banking industry: Evidence from a Greek commercial bank. Applied Economics 21: 285-93. [CrossRef]

Portela, Maria Conceiçao A. Silva, and Emmanuel Thanassoulis. 2007. Comparative efficiency analysis of Portuguese bank branches. European Journal of Operational Research 177: 1275-88. [CrossRef]

Samitas, Aristeidis, and Stathis Polyzos. 2016. Freeing Greece from capital controls: Were the restrictions enforced in time? Research in International Business and Finance 37: 196-213. [CrossRef]

Schaffnit, Claire, Dan Rosen, and Joseph C. Paradi. 1997. Best practice analysis of bank branches: An application of DEA in a large Canadian bank. European Journal of Operational Research 98: 269-89. [CrossRef]

Shamim, Farkhanda, Nobuyoshi Yamori, and Shahid Anjum. 2017. Clicks business of deposit-taking institutions: An efficiency analysis. Journal of Economic Studies 44: 911-30. [CrossRef]

Sherman, David H., and Franklin Gold. 1985. Bank branch operating efficiency. Evaluation with data envelopment analysis. Journal of Banking and Finance 9: 297-315. [CrossRef]

Sherman, David H., and George Ladino. 1995. Managing bank productivity using data envelopment analysis. Interfaces 25: 60-73. [CrossRef]

Soteriou, Andreas, and Stavros A. Zenios. 1999. Operations, quality and profitability in the provision of banking services. Management Science 45: 1221-38. [CrossRef]

Spiezia, Vincenzo. 2003. Measuring Regional Economies. In OECD Statistics Brief. No. 6. Paris: OECD.

Spokeviciute, Laima, Kevin Keasey, and Francesco Vallascas. 2019. Do financial crises cleanse the banking industry? Evidence from us commercial bank exits. Journal of Banking E Finance 99: 222-36.

Stournaras, Yannis. 2019. Lessons from the Greek crisis: Past, present, future. Atlantic Economic Journal 47: 127-35. [CrossRef]

Tan, Yong, and Christos Floros. 2012. Bank profitability and inflation: The case of China. Journal of Economic Studies 39: 675-96. [CrossRef]

Tan, Yong, and Christos Floros. 2013. Risk, capital and efficiency in Chinese banking. Journal of International Financial Markets, Institutions and Money 26: 378-93. [CrossRef]

Tan, Yong, and Christos Floros. 2014. Risk, profitability and competition: Evidence from the Chinese banking industry. Journal of Developing Areas 48: 303-49. [CrossRef]

Tan, Yong, and Christos Floros. 2018. Risk, competition, and efficiency in banking: Evidence from China. Global Finance Journal 35: 223-36. [CrossRef]

Tan, Yong, and Christos Floros. 2020. Risk, competition and efficiency in the Chinese banking industry. International Journal of Banking, Accounting, and Finance 10: 144-61. [CrossRef]

Tziogkidis, Panagiotis, Kent Matthews, and Dionisis Philippas. 2018. The effects of sector reforms on the productivity of Greek Banks: A step-by-step analysis of the pre-Euro Era. Annals of Operations Research 266: 531-49. [CrossRef]

Valverde, Santiago Carbo, David B. Humphrey, and Rafael Lopez del Paso. 2007. Do cross-country differences in bank efficiency support a policy of "national champions"? Journal of Banking \& Finance 31: 2173-88.

Vassiloglou, Myrto, and Dimitrios Giokas. 1990. A study of the relative efficiency of bank branches: An application of data envelopment analysis. The Journal of the Operational Research Society 41: 591-97. [CrossRef]

Walter, Ingo. 1999. Financial service strategies in the euro-zone. EIB Cahiers Papers 4: 145-68. [CrossRef]

Williams, Jonathan, and Edward Gardener. 2003. The efficiency of European banking. Regional Studies 37: 321-30. [CrossRef]

Wu, Desheng, Yang Zijiang, and Liang Liang. 2006a. Using DEA-neural network approach to evaluate branch efficiency of a large Canadian bank. Expert Systems with Applications 31: 108-15. [CrossRef] 
Wu, Desheng, Yang Zijiang, and Liang Liang. 2006b. Efficiency analysis of cross-region bank branches using fuzzy data envelopment analysis. Applied Mathematics and Computation 181: 271-81. [CrossRef]

Zilberfarb, Ben-Zion. 1989. The effect of Automated Teller Machines on demand deposits: An empirical analysis. Journal of Financial Services Research 2: 49-57. [CrossRef]

Publisher's Note: MDPI stays neutral with regard to jurisdictional claims in published maps and institutional affiliations.

(C) 2020 by the author. Licensee MDPI, Basel, Switzerland. This article is an open access article distributed under the terms and conditions of the Creative Commons Attribution (CC BY) license (http://creativecommons.org/licenses/by/4.0/). 